\author{
AN ARTICLE \\ Submitted in the Partial fulfillment of Requirements \\ for the Degree of Sarjana Pendidikan
}

By:

JUNI ANTO MANULLANG

Registration Number. 2122121020

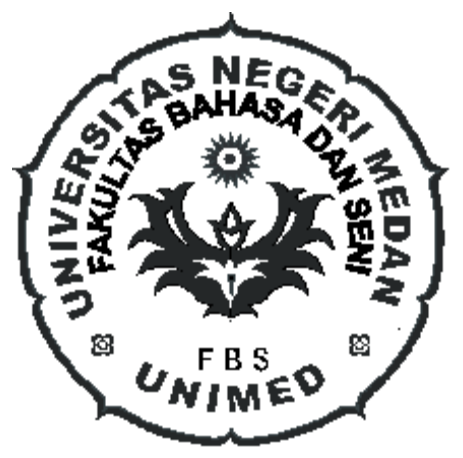

ENGLISH AND LITERATURE DEPARTMENT

FACULTY OF LANGUAGES AND ARTS

STATE UNIVERSITY OF MEDAN

2017 


\begin{abstract}
ARTIKEL
THE EFFECET OF USING CIRC IN TEACHING WRITING NARRATIVE TEXT AT GRADE XI STUDENTS OF SENIOR HIGH SCHOOL
\end{abstract}

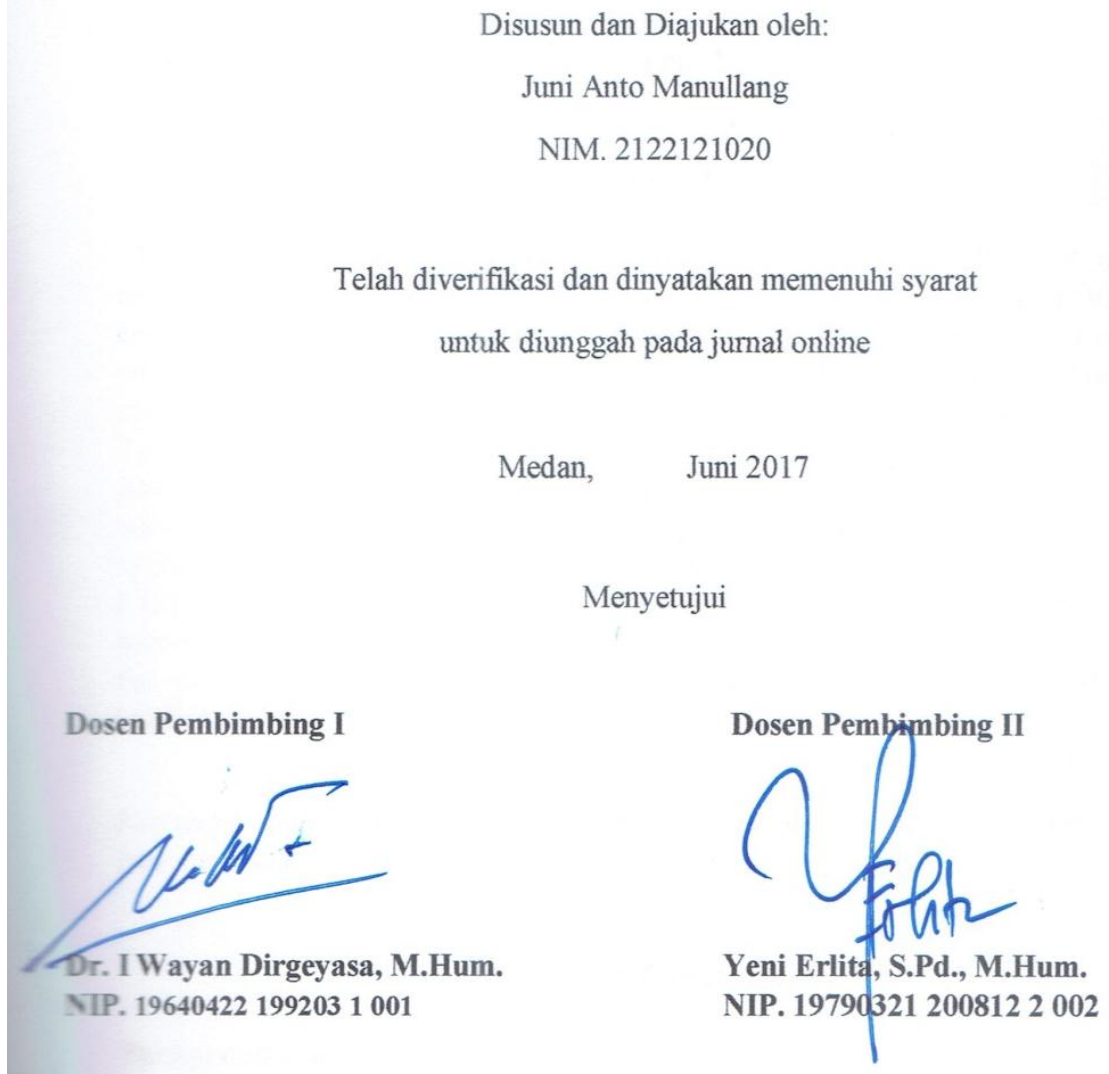

Ka. Prodi Studi

Pendidikan Bahasa Inggris

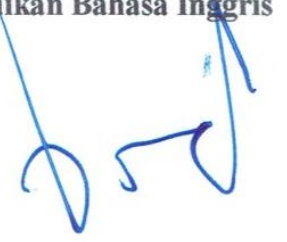

Nora Ronita Dewi, S.Pd., S.S., M.Hum.

NIP. 198005222008122003 


\title{
THE EFFECT OF USING CIRC IN TEACHING WRITING NARRATIVE TEXT AT GRADE XI STUDENTS OF SENIOR HIGH SCHOOL
}

\author{
*Juni Anto Manullang \\ **I Wayan Dirgeyasa \\ ****Yeni Erlita
}

\begin{abstract}
The objective of this study was to find out whether the effect of using CIRC technique in writing narrative can improve students' achievement in writing narrative text. It was conducted by using experimental research. The population of this study was eleventh grade of SMAN 1 Siempat Nempu Hulu, which was consisted of 4 classes. Two classes were taken as the sample by using random sampling technique. The class XI IPA 1 was as experimental group and XI IPA 2 was as the control group. The experimental group was taught by using CIRC, otherwise control group was taught by using conventional technique. The instrument for collecting data was writing test. The data were analyzed by using t-test formula. The result shows that CIRC has a significant effect on students achievement in writing narrative text. The result shows that the t-observed is higher than $t$-table $(3.102>2.024(\alpha=0.05))$ with the degree of freedom $(\mathrm{df})=20$. Therefore, CIRC significantly affects on the students' ability in writing narrative text.
\end{abstract}

Keyword: Cooperative Integrated Reading and Composition (CIRC), Writing, Narrative text.

\section{INTRODUCTION}

\section{Background of the Study}

Writing is one of an important activity to communicate. People who live in different places really need writing to communicate each other.

* A graduate of English and Literature Department of UNIMED

** Lecturer of English and Literature Department of UNIMED

*** Lecturer of English and Literature Department of UNIMED 
According to Saragih \& Anggraini (2014:1) Writing is defined as an activity in which a person represents one's experience in the medium of written expressions using acceptable linguistic forms.

Based on the curriculum of Junior High School (KTSP:2006), students are expected to be able to write paragraphs of description, recount, narrative, procedure and etc. The researcher focuses on students' ability in writing narrative text.

Based on researcher's experience observation on teaching training and his observation in SMA Negeri 1 Siempat Nempu Hulu, he found that there were some problems that faced by students in writing activity, such as the using of correct grammar and learning technique or strategies used by the teacher. They failed to arrange the structure of their story because they did not understand the generic structure of it. They got confused in using of present or past form in their tenses, whether it is subject or object, and many other problems. Several of them are not interested to write. Even, they did not write anything on their paper.

In teaching and learning activity, the teacher need to use various method or strategy to gain the students' interest. The use of inappropriate and unattractive teaching strategy that had been applied could significantly influence teaching and learning process. In addition, teaching learning process could be affected by the lack of students' motivation to study. If the process of teaching and learning are boring and monotonous, the students will have no interest in studying and will cause a bad result (Sharon: 2003). 
This problem can be solved by implementing new learning technique in teaching and learning process. Cooperative Integrated Reading and Composition is an appropriate technique for teaching writing. CIRC provides students to work collaboratively, help each other as a team, and correct their work in team. So, it will help them to solve their writing difficulties. By using this technique, students are hoped to be more motivated to improve their ability in writing.

It has been proved that story mapping is a beneficial teaching strategy based on the references found by the researcher. Moreover, CIRC can help students to motivate them in writing. As Durukan (2009) states that CIRC is a comprehensive program for teaching reading and writing in which students are composed of pairs of students from two or more different level.

By considering the explanation above, the researcher conducted a research to find out the effect of Cooperative Integrated Reading and Composition will affect students' achievement in writing narrative text.

\section{Research Question}

In line with the background of the study, the problem of the study is: "is there any significant effect on students' achievement in writing narrative text through CIRC technique?" 


\section{Writing Skill}

\section{REVIEW OF LITERATURE}

Hyland (2002:6), states that writing as a textual product, a coherent arrangement of elements structured according to a system of rules. Brown (2004:218) states the ability to write has become an indispensable skill in our global literate community. It means that the ability of writing is really needed by any job, especially surrounded by the educational area.

Writing is away to produce language and express idea, feeling and opinion (Harmer :2004). Furthermore, he states that writing is a process that what we write is often heavily influenced by the constraints of genre, and then these elements have to be present in learning activities. Therefore, writing does not only talk about the result, but it also can be used as a part of larger activity such as speaking and acting out.

From the definition above, the researcher can conclude that writing is a way to produce language by putting down words or ideas to some medium. And it is a learned process that takes time and concentrated practice because the researcher has more time to think than they do in oral activities.

Writing process is the steps which guide us to start writing and finally get the final good writing. According to Harmer (2004), the process of writing has four elements:

1) Planning : an activity of writing that aimed to encourage and stimulate the students to write; 
2) Drafting : the students will focus on the fluency of writing and focus on the content and the meaning of the writing;

3) Editing (Reflecting and Revising) : the students are reviewed and helped by other readers who comment and give suggestion;

4) Final Version : writer has edited their draft, making the changes that the writer considers being necessary, and the writer produces the final version.

\section{Narrative Text}

Narration is any written English text in which the writer wants to amuse, entertain people, and to deal with actual or vicarious experience in different ways (Siahaan and Shinoda: 2008). In addition, Knapp and Watkins (2005: 221) state that narrative also has a powerful social role beyond that of being a medium for entertainment. Narrative is also a powerful medium for changing social opinions and attitude

\section{a. Generic Structure of Narrative Text}

Dirgeyasa (2014), describe the generic structure of narrative text as folows:

Textual Elements

Orientations

\section{Functions}

- It consists of theme or topic to be informed

- Introducing the characters of the story, the time and the place story happened (who, what, when, and where)

- It enables to attract and to provoke the reader so that he/she is willing to continue reading the whole text. 
Complication

Resolution

(Dirgayasa, 2014. College Academic Writing: a genre based perspective)
- A series of events in which the main character attempts to solve the problem

- The complication ususally involves the main characte(s) (often mirroring the complications in real life)

- The endings of the story containing the problem solution

- The complication may be resolved for better or worse /happily or unhappily.

- Sometimes there are a number of complications that have to be resolved. There add and sustain interest and suspense for the reader.

\section{b. Grammatical Features of Narrative Text}

According to Dirgayasa (2014), the common grammatical language features of narrative witing as:

a) It mostly often uses the past tense, but may be in the immediate present for effect.

b) It varies in sentence length; simple, compound or complex.

c) It tends to short sentences to increase tension; longer sentences provide contrast and detail.

d) The use of dialogue will develop action and characters.

e) Tense may change within dialogue. 
f) Active nouns; Make nouns actually do something. e.g. "It was raining" could become "Rain splashed down" or "There was a large cabinet in the lounge" could become "A large cabinet seemed to fill the lounge".

g) Be careful use of adjectives and adverbs; Writing needs judicious use of adjectives and adverbs, quality the action and provide description and information for the reader.

\section{Cooperative Integrated Reading and Composition (CIRC)}

CIRC is a comprehensive program for teaching reading and writing in which students are assigned to teams composed of pairs of students from two or more different level, (Durukan, 2011). As stated by Slavin (1995) that CIRC is a comprehensive program for teaching reading and writing in the upper elemntary and middle grades. Therefore, students can achieve the goals of learning only when they work together. This CIRC technique is mainly used to teach reading and composition and has been found to be effective when used in teaching reading and writing (Durukan, 2011). In cooperative learning, students are charged to help each other. The expected outcome of CIRC is to promote higher student achievement by promoting more social and academic interactions.

\section{Teaching Writing Narrative Through CIRC}

In writing, there are several technique that are commonly used to increase student ability in narrative. Here, the researcher is interested in using CIRC for teaching writing. Here is the scenario : 
Table 1. The Scenario of Teaching

\begin{tabular}{|c|c|}
\hline Session & Activities \\
\hline Opening & $\begin{array}{l}\text { 1. Teacher greeted student } \\
\text { 2. teacher cheeked the students' attendance }\end{array}$ \\
\hline Main Activity & $\begin{array}{l}\text { 1. Teacher asks the students to mke group that consists of } \\
\text { 4-5 students each group } \\
\text { 2. Teacher explain about narrative text and elaborate its } \\
\text { generic structure and grammatical features } \\
\text { 3. Teacher provided an example of traditional story from } \\
\text { Indonesia } \\
\text { 4. Teacher asks the students to write a narrative text } \\
\text { independently in group } \\
\text { 5. The students show their work to their partner, check } \\
\text { each other and correct the mistakes that their partner } \\
\text { made } \\
\text { 6. After that, the students are asked to write a narrative } \\
\text { text in group, one text for each group. } \\
\text { 7. Teacher asked them to write a text about Legend of } \\
\text { Lake Toba independently. } \\
\text { 8. Then, teacher asked students to come in front of the } \\
\text { class and shows their writing. }\end{array}$ \\
\hline Closing & Teacher made a conclusion and gave feed back \\
\hline
\end{tabular}

\section{RESEARCH METHOD AND DISCUSSION}

\section{Research Design}

This research was conducted in an experimental research design. The research was conducted to investigate the effect of CIRC on students' achievement in writing narrative text. There were two groups used in conducting this research namely experimental and control. The experimental group received treatment by applying CIRC and the control group by using conventional technique. The design of this research culd be seen as the following: 
Table 2 True Experimental Design

\begin{tabular}{llll}
\hline Group & Pre - test & Independent Variable & Post - test \\
\hline $\mathrm{E}$ & $\mathrm{Y}_{1}$ & $\mathrm{X}$ & $\mathrm{Y}_{2}$ \\
$\mathrm{C}$ & $\mathrm{Y}_{1}$ & - & $\mathrm{Y}_{2}$ \\
\hline & & & (source: Donald Ary, 2002:308)
\end{tabular}

In which:

$\mathrm{Y}_{1} \mathrm{E} \quad=$ Pre-test of experimental group

$\mathrm{Y}_{2} \mathrm{E}=$ Post-test of experimental group

$\mathrm{X}=$ Treatment

$\mathrm{Y}_{1} \mathrm{C}=$ Pre-test of control group

$\mathrm{Y}_{2} \mathrm{C}=$ Post-test of control group

The population of this research was taken from the eleventh grade students of SMA Negeri 1 Siempat Nempu Hulu. The eighth grade students consisted of 4 classes. The total number of students was 104 students and each class consisted of 26 students. The sample consisted of two classes (XI IPA-1 as the experimental group and XI IPA-2 as control group) that were taken by using cluster sampling. It represented the entire population which consisted of 26 students. Then, the sample of this research was selected randomly by taking 20 students for experimental and control classes through Two-Stage Cluster Sample by the lottery method.

The researcher used writing test as the instrument of collecting data and it was administered to both experimental and control groups. The writing test contained some instructions for guiding students to make a narrative text. The writing test was given in order to find out the score of experimental and control group and to see whether the students' writing ability after being taught by using 
CooperativeIntegrated Reading and Composition in experimental group was different significance.

\section{ANALYSIS AND FINDINGS}

Writing test was given to the students to obtain the data. The cumulative score of every students' writing from both experimental and control group is based on four aspects in scoring narrative text: audience and purpose, organization, elaboration and the use of languange. After conducting the research, the researcher got the data of students' scores in pre-test and post-test from both experimental and control group. The data were needed for hypothesis testing. Here are the data:

Table 4. The Result of Pre-Test and Post-Test in Experimental Group

\begin{tabular}{llccc}
\hline \multirow{2}{*}{$\begin{array}{l}\text { Statistical } \\
\text { Calculation }\end{array}$} & \multicolumn{3}{c}{ Pcore } \\
\cline { 2 - 5 } & $\begin{array}{l}\text { Experimental } \\
\text { Group }\end{array}$ & $\begin{array}{l}\text { Control } \\
\text { Group }\end{array}$ & $\begin{array}{c}\text { Experimental } \\
\text { Group }\end{array}$ & $\begin{array}{c}\text { Control } \\
\text { Group }\end{array}$ \\
\cline { 2 - 5 } & 56.2 & 55.3 & 78.7 & 68.6 \\
$\bar{x}$ & 10.41 & 12.22 & 7.64 & 11.8 \\
SD & 2.39 & 2.80 & 1.75 & 2.54 \\
SE & 31 & 31 & 63 & 50 \\
Lowest & 75 & 75 & 94 & 87 \\
Highest & 1124 & 1106 & 1574 & 1372 \\
Sum & & & & \\
\hline
\end{tabular}

From the data, it was found that the mean score of the students in pre-test of experimental group was 56.2, while the mean score in pre-test of control group was 55.3. the standard deviation of the students' score in pre-test experimental group was 10.41 while the standard deviation of students' score in pre-test control group was 12.22. The standard error of the students' score in pre-test of 
experimental group was 2.39 while the standard error of students' score in pre-test of control group was 2.80. The mean score of students in post-test of experimental group was 78.7, while the mean score of students in post-test was 68.6. The standard deviation of the students' score in post-test of experimental group was 7.64, while the standard deviation of students' score in post-test of control group was 11.8. The standard error of students' score in post-test of experimental group was 1.75 , while the standard error of students' score in posttest of control group was 2.54. The lowest score of the students in experimental group was 31 for pre-test and 63 for post-test. The lowest score of the students in control group was 31 for pre-test and 63 for post-test.

The highest score of the students in experimental group was 75 for pre-test and 94 for post-test. The highest score of the students' score in control group was 75 for pre-test and 87 for post-test. From the data above, it can be seen from the lowest and highest score of pre-test and post-test that applying CIRC significantly affects students' achievement in writing narrative text. The hypothesis aimed to know whether the null hypothesis was accepted or rejected. Because the value $t_{o}$ (3.102) exceeded the value of t-table (2.024) with $\alpha=0.05$ and $\mathrm{df}=38$, the null hypothesis (Ho) had been successfully rejected). Thus, the formulated hypothesis, "Students' achievement taught by using CIRC is higher than that taught by using conventional technique" is really true in this research. 
The result of this research showed that there was a difference of output of both groups. Based on statistic calculation, the mean of experimental group and control group was different. The mean score of experimental group was higher that control group. Based on theoritical and statistical findings, the researcher concludes that there is higher significant effect of CIRC technique on students' achievement in writing narrative text.

\section{Discussion}

There was a significant difference on students ' achievement in writing narrative text between experimental and control group. The students that were taught by using CIRC had higher scores than the students that were taught conventionally.

Students' ability in writing narrative text by using Cooperative Integrated Reading and Composition was better than students' ability in writing narrative text by using conventional technique. It is shown by the scores of the students. It is because CIRC made writing class more fun and enjoyable for students, and the students became enthusiastic to learn because it ease them in writing activity. They have to work collaboratively, share their ideas and work each other, and checked their work each other. It was different in conventional teaching class where the students learnt very passive and less enthusiastic to learn.

Based on the explanation above, it was supported by the result of Sara Frimaulia (2013) conducted a research entitled the effect of applying Cooperative Integrated Reading and Composition (CIRC) Technique on Students Achievement in 
Writing Recount Text. The finding of previous research are the students can improve their writing ability and more enjoyable in learning writing through CIRC.

The difference is the previous research is about CIRC used in teaching writing recount and the current research is the CIRC used in teaching writing narrative. The finding of previous research are the students can improve their writing ability and more enjoyable in learning writing through CIRC.

Another research by Himawati (2011) had conducted a research about The Use of Cooperative Integrated Reading and Composition (CIRC) to Improve students' ability in Composing Narrative Writing. Both of the previous and current research applied CIRC in teaching writing narrative text. The difference is the previous research conducted in Junior High School while the current research conducted in Senior High School. In te previous research, she found that CIRC significantly affects on students' writing ability.

Imam Suhadi (2013) conducted a research about the using of CIRC to teach writing. His research was about the using of CIRC in writing narrative text viewed from students' intelligence. He found that students who taught through CIRC will be more active and interested in writing class, and the teacher not only teaches the academic content, but also considers making the students develop their social relation with other students. The result of his research and the current research show that CIRC has a significant effect on students' writing ability 
Based on the explanation, it can be conluded that the implementation of Cooperative Integrated Reading and Composition (CIRC) has significant affect students' writing skill in writing narrative text.

\section{SUGGESTIONS}

In the relation to the conclusion above, the researcher points out some suggestion as following. The English teachers are suggested to apply story mapping strategy in teaching narrative text as the alternative in teaching learning process because is proved effective to improve writing ability; Since this research is limited to the investigation of the story mapping strategy on writing and how the story mapping strategy can be developed is not known, it is suggested that a research should be done on writing development.

\section{REFERENCES}

Anggraini, T and Amrin. 2014. Course Book Writing. Medan: Unimed Press.

Ary, Donald. 2002. Introduction to Research in Education. Singapore: Wardswith.

Best, J. W. \& Kahn, J. V. 2006.Research in Education (10th edition). New York: Pearson Education.

Brown, H. D. 2004. Language Assesment: Principles and Classroom Practice. New York: Longman.

Dirgayasa, I Wy. 2014. Academic Writing: a genre based approach. First published. Medan: Unimed Press. 
Durukan Erhan. 2011. Effects of cooperative integrated reading and composition (CIRC) technique on reading -writing skills. Academic journal. No.1, Vol. $6(102-109)$

Frimaulia Sara. 2013. The Effect of Applying Cooperative Integrated Reading and Composition (CIRC) Technique on Students' Achievement in Writing Recount Text. Medan: Unimed Library.

Harmer, J. 2004. How to Teach Writing. England: Longman.

Himawati, U. 2011. The Use of Cooperative Integrated Reading and Composition (CIRC) to Improve Students' Ability in Composing Narrative Writing. Published Thesis: Semarang: IAIN Walisongo Semarang Library.

Hyland, k. 2002. Teaching and Researching Writing: Applied Linguistics in Action Series. Pearson Education: Longman.

Slavin, Cooperative Learning: Theory, Reseach, and Practice, (USA: Allynand Bacon, 1995), 2nd Ed, p. 104.

Suhadi, I. 2013. The Effectiveness of Cooperative Integrated Reading and Composition (CIRC) to Teach Writing Viewed From Students' Intelligence: Unpublished Thesis. Surakarta: Universitas Sebelas Maret Library. 